\title{
Rationality analysis of urban spatial distribution and development direction based on environmental impact assessment-On to the Jianghua Yao nationality autonomous county
}

\author{
Zhe $\mathrm{Li}^{1}$, Yidan Wang ${ }^{2}$, and Shuyuan Tong * \\ ${ }^{12 *}$ School of Architecture and Art, Central South University, ChangSha, China
}

\begin{abstract}
The rational planning of urban spatial distribution and development direction could benefit the urban economy, social environment and other aspects, as an essential part of urban planning. Since the Law of EIA promulgated in 2003, the scope of environmental impact assessment has been upgraded to a higher level of overall urban planning whereas the influence is not significant. In 2018, urban and rural planning function was merged into the Ministry of Natural Resources, from leading urban construction to serving the protection of urban natural resources. It is also a new and significant approach to analyse the rationality of urban spatial distribution and development direction from the perspective of environmental impact assessment. The purpose of Jianghua Yao autonomous county is to build an eco-tourism civilized city, which is representative in the selection of cities for environmental impact assessment. On the space structure of functional areas and the development direction to the indicator elements of Yao nationality autonomous county class was divided into 4 categories, 5 layers, 15 index factors were selected to construct the environmental impact assessment index system. Using analytic hierarchy process (AHP) to select the indexes weights assignment, then according to the evaluation criterion to evaluate it, we draws the analysis conclusion in the environment aspect. The planned urban spatial distribution and development direction of Jianghua Yao autonomous county from 2014 to 2020 are reasonable, have little negative impact on the environment, and are suitable for the green development of the city.
\end{abstract}

\section{Introduction}

Since the Law of EIA promulgated in 2003, the scope of environmental impact assessment has been upgraded to a higher level of overall urban planning whereas the influence is not significant. In 2018, urban and rural planning function was merged into the Ministry of Natural Resources, from leading urban construction to serving the protection of urban natural resources. The traditional method to determine the spatial distribution and development direction of the city is to delimit the four districts, evaluate the suitability of construction land and determine the function, nature and development direction of the city based on the analysis of urban development conditions. Some scholars put forward the urban development preference model and farmland loss model based on the smart growth of urban spatial development direction to identify the "smart" spatial expansion direction of the urban ${ }^{[1]}$ or use land suitability evaluation to carry out land use planning for urban sustainable development ${ }^{[2]}$. GIS also contains analytical tools to help with urban problems, providing the user with extra useful functionality ${ }^{[3]}$. But they all lack of consideration of the perspective of environment. Therefore, this paper will evaluate the overall planning of Jianghua from the perspective of environmental impact and draw a conclusion.

\section{Construction of environmental evaluation index system}

\subsection{Overview of Jianghua county}

Jianghua Yao autonomous county is located in the south of YongZhou city, Hunan province. According to the general urban planning of Jianghua Yao autonomous county (2014-2020), the urban space is divided into industrial zone group, living zone group and tourist zone group, etc., and the development direction of land is determined to be east-west and northward extension.

The new urban construction and functional layout may cause various ecological damage to the city, including the fragmentation of the ecological environment, the decline 
of its stability, the change of biodiversity, the decline of environmental function, and the damage of water, soil and atmosphere ${ }^{[4]}$. This study mainly discusses the spatial distribution and development direction of the city. Therefore, the construction of roads, bridges, water supply and drainage, the construction of various functional areas and other projects will have different degrees of impact on the local water environment, air environment, acoustic environment, society and ecological environment ${ }^{[5]}$. This study mainly takes the above several environmental index levels in each partition as an example to conduct research.

\subsection{Determination of environmental assessment index factors}

According to the requirements of the overall plan for Jianghua county, from the space distribution and the development direction into consideration, the county environmental evaluation index system is divided into four major categories. The factors index layer is divided into 5 layers. Tab. 1 is obtained according to the impact analysis between different element layers.

Table 1. Influence Analysis of Element Layer.

\begin{tabular}{|c|c|c|c|c|}
\hline & $\begin{array}{c}\text { Road } \\
\text { Traffic }\end{array}$ & $\begin{array}{c}\text { Industri } \\
\text { al Area }\end{array}$ & $\begin{array}{c}\text { Living } \\
\text { Area }\end{array}$ & $\begin{array}{c}\text { Tourist } \\
\text { Area }\end{array}$ \\
\hline $\begin{array}{c}\text { The Water } \\
\text { Environment }\end{array}$ & $\star$ & $\star \star \star$ & $\star \star \star$ & $\star \star$ \\
\hline Air Quality & $\star \star \star$ & $\star \star \star$ & $\star \star$ & $\star$ \\
\hline $\begin{array}{c}\text { Acoustic } \\
\text { Environment }\end{array}$ & $\star \star$ & $\star$ & $\star \star$ & $\star$ \\
\hline Solid Waste & $\star$ & $\star \star$ & $\star \star \star$ & $\star \star \star$ \\
\hline Landscape & $\star$ & $\star \star$ & $\star \star$ & $\star \star$ \\
\hline
\end{tabular}

NOTE:

Small impact; $\star \star$ Moderate impact;

Greater impact

\subsection{Construction of environmental impact assessment index system}

Generally, the concept of sustainable development in urban development planning is taken into account and economic, environmental and social objectives are harmonized ${ }^{[6]}$. According to the overall plan of Jianghua county, its urban spatial distribution and development direction will affect the water, atmosphere, acoustic environment and ecological environment, and generate solid waste. According to the factor impact table, the water environment is mainly affected by industrial areas and living areas. Therefore, the main index factors are the quality compliance rate $(\%)$ of the centralized drinking water source, the water quality compliance rate $(\%)$ of the water function area, and the regional domestic sewage treatment rate $(\%)$. Atmospheric environment is mainly affected by road traffic and industrial zone, so the main index factors are environmental air quality (API) excellent rate $(\%)$, pollutant emission intensity (sulfur dioxide, ammonia nitrogen). The acoustic environment is mainly affected by the traffic and living environment. Therefore, the average sound level on both sides of urban trunk lines $[\mathrm{dB}(\mathrm{A})]$ and the compliance rate of urban noise environmental quality (\%) were 2 . Solid waste is mainly affected by industrial areas and living areas, so the index factors are industrial solid waste disposal utilization rate $(\%)$ and household waste harmless treatment rate $(\%)^{[7]}$. All functional areas of ecological landscape environment have influences, so the evaluation index factors are vegetation coverage rate, biological abundance index, county ecological environment status index (EI), water network density index ${ }^{[8]}$. The index system is shown in the following table.

Table 2. Element Layer Analysis.

\begin{tabular}{|c|c|c|}
\hline Index Element Layer & Evaluation Objective & Evaluation Index \\
\hline $\begin{array}{l}\text { The water } \\
\text { environment }\end{array}$ & $\begin{array}{l}\text { Water environment related elements are } \\
\text { selected for planning and evaluation }\end{array}$ & $\begin{array}{l}\text { Water quality standard rate of centralized drinking } \\
\text { water source }(\%) \\
\text { Water function area water quality standard rate }(\%) \\
\text { Regional sewage treatment rate }(\%)\end{array}$ \\
\hline Air quality & $\begin{array}{l}\text { Selected elements related to atmospheric } \\
\text { environment for planning and evaluation }\end{array}$ & $\begin{array}{c}\text { Ambient air quality (API) good rate (\%) } \\
\text { Pollutant emission intensity (sulfur dioxide, ammonia } \\
\text { nitrogen) }\end{array}$ \\
\hline Acoustic environment & $\begin{array}{c}\text { The relevant elements of noise } \\
\text { environment are selected for planning and } \\
\text { evaluation }\end{array}$ & $\begin{array}{l}\text { Diurnal mean sound level on both sides of city main } \\
\quad \text { line }[\mathrm{dB}(\mathrm{A})] \\
\text { Urban noise environment quality standard rate }(\%)\end{array}$ \\
\hline Solid waste & $\begin{array}{l}\text { Solid waste environmental factors were } \\
\text { selected for planning and evaluation }\end{array}$ & $\begin{array}{l}\text { Utilization rate of industrial solid waste disposal }(\%) \\
\text { Household garbage harmless disposal rate }(\%)\end{array}$ \\
\hline Ecological landscape & $\begin{array}{l}\text { Selected ecological landscape } \\
\text { environment related elements for } \\
\text { planning and evaluation }\end{array}$ & $\begin{array}{c}\text { Vegetation coverage }(\%) \\
\text { Biological abundance index }(\%) \\
\text { County ecological environment index (EI) } \\
\text { Water network density index }\end{array}$ \\
\hline
\end{tabular}


Table 3. Index System of Environmental Impact Assessment.

\begin{tabular}{|c|c|c|}
\hline $\begin{array}{l}\text { Evaluation Index } \\
\text { Element Layer }\end{array}$ & Index Factor & Evaluation Index Unit \\
\hline $\begin{array}{l}\text { Road traffic impact layer } \\
\qquad \text { B1 }\end{array}$ & $\begin{array}{c}\text { Diurnal mean sound level on both sides of city main line } \mathrm{c} 1 \\
\text { Traffic accessibility } \mathrm{c} 2 \\
\text { Industrial sewage treatment rate } \mathrm{c} 3\end{array}$ & $\begin{array}{c}\mathrm{dB}(\mathrm{A}) \\
\text { Excellent/good/poor } \\
\% \\
\%\end{array}$ \\
\hline $\begin{array}{c}\text { Industrial area affected } \\
\text { layer B2 }\end{array}$ & $\begin{array}{c}\text { Utilization rate of industrial solid waste disposalc4 } \\
\text { Pollutant emission intensity (sulfur dioxide, ammonia } \\
\text { nitrogen) compliance ratec5 }\end{array}$ & $\begin{array}{l}\% \\
\%\end{array}$ \\
\hline $\begin{array}{l}\text { Living area influence } \\
\text { layer B3 }\end{array}$ & $\begin{array}{c}\text { Ambient air quality (API) good ratec6 } \\
\text { Urban noise environment quality standard ratec } 7 \\
\text { Household garbage harmless disposal ratec } 8 \\
\text { Regional sewage treatment ratec } 9 \\
\text { Water quality standard rate of centralized drinking water } \\
\text { sourcec } 10 \\
\text { Water function area water quality standard ratec } 11\end{array}$ & $\begin{array}{l}\% \\
\% \\
\% \\
\% \\
\% \\
\%\end{array}$ \\
\hline $\begin{array}{c}\text { Tourist area influence } \\
\text { layer B4 }\end{array}$ & $\begin{array}{c}\text { Vegetation coveragec12 } \\
\text { Biological abundance indexc13 } \\
\text { Water network density indexc14 } \\
\text { County ecological environment index (EI) c15 }\end{array}$ & $\begin{array}{c}\% \\
1 \\
1 \\
1\end{array}$ \\
\hline
\end{tabular}

\section{Environment evaluation index system of weight assignment}

AHP is a more appropriate research method for urban development problems generally considered as social problems ${ }^{[9]}$. For the complex system of planned regional economic environment, the contributions of various levels of elements are different, that is, the whole system has different response degrees to the changes of different elements. Therefore, as an expression of the environmental impact characteristics of the planning area, the importance and weight of the indicators should be distinguished in the planning environmental impact assessment index system, that is, different indicators should be given different weights. Evaluation for urban sustainable development is significant to improve the future development of urban [10]. This paper adopts "Analytic Hierarchy Process" by assigning weights at different levels, which can avoid the confusion and mistakes of subjectiveness and a large number of indicators simultaneously, which is conducive to improving the simplicity and accuracy of prediction and evaluation. The index system contains quantitative and qualitative data indexes. Therefore, in the process of data analysis, this paper adopts both qualitative analysis method and semi-quantitative analysis method.

\subsection{Analytic hierarchy process (AHP)}

The rationality of urban spatial distribution and development direction is taken as the target layer of AHP and the environmental impact assessment of rail transit, living area, industrial area and tourist area is taken as the evaluation factor layer. The lowest layer is the detailed and specific indicators determined by screening ${ }^{[11]}$.
Hierarchy reflects the relationship between factors, but the proportion of each criterion in the criterion layer is different in different decision makers. When it comes to certain issues, some elements may have different ideas for each person, so for such elements, it is not easy to get accurate evaluation results, or even contradictory [12]. Hence the AHP presents the novel idea on the issues that will promote further development. Firstly, there is Tab.4 of Importance Level and Its Apportionment ${ }^{[13]}$.

Table 4. Importance Level and Its Assignment.

\begin{tabular}{|c|c|}
\hline Scale & Meaning \\
\hline 1 & $\mathrm{C}_{\mathrm{i}}$ and $\mathrm{C}_{\mathrm{j}}$ is the same \\
\hline 3 & $\mathrm{C}_{\mathrm{i}}$ is slightly stronger than $\mathrm{C}_{\mathrm{j}}$ \\
\hline 5 & $\mathrm{C}_{\mathrm{i}}$ is stronger than that of $\mathrm{C}_{\mathrm{j}}$ \\
\hline 7 & $\mathrm{C}_{\mathrm{i}}$ is obvious stronger than that of $\mathrm{C}_{\mathrm{j}}$ \\
\hline 9 & $\mathrm{C}_{\mathrm{i}}$ is absolutely stronger than that of $\mathrm{C}_{\mathrm{j}}$ \\
\hline $2,4,6,8$ & $\begin{array}{c}\mathrm{C}_{\mathrm{i}} \text { element to } \mathrm{C}_{\mathrm{j}} \text { element is between the } \\
\text { two adjacent levels mentioned above. }\end{array}$ \\
\hline $1,1 / 2, \ldots, 1 / 9$ & $\begin{array}{c}\mathrm{C}_{\mathrm{i}} \text { element to } \mathrm{C}_{\mathrm{j}} \text { element is the reciprocal } \\
\text { number of All above. }\end{array}$ \\
\hline
\end{tabular}

\subsection{Evaluation index synthesis}

According to the index system, by the above scale method and through the questionnaire survey of expert consultation, 8 experts in this field were selected to grade the importance of the index and the scoring results were discussed and summarized internally, while the parewise discriminant matrix was obtained as follows ${ }^{[14]}$.

Table 5. Discriminant Matrix.

\begin{tabular}{|c|c|c|c|c|}
\hline & B1 & B2 & B3 & B4 \\
\hline B1 & 1 & $1 / 2$ & $1 / 4$ & $1 / 3$ \\
\hline B2 & 2 & 1 & $1 / 3$ & $1 / 2$ \\
\hline B3 & 4 & 3 & 1 & 2 \\
\hline B4 & 3 & 2 & $1 / 2$ & 1 \\
\hline
\end{tabular}


MATLAB was used to calculate the maximum characteristic root of the judgment matrix $\lambda_{\max }=4.0310$. Consistency test of judgment matrix is carried out to calculate the consistency index:

$$
C I=\frac{\lambda_{\max }-n}{n-1}=\frac{4.0310-4}{4-1}=0.0103
$$

Mean random consistency index. Random consistency ratio:

$$
C R=\frac{C I}{R I}=\frac{0.0103}{0.9}=0.0115<0.10
$$

Therefore, the results of AHP have satisfactory consistency, that is, the distribution of weight coefficient is very reasonable. MATLAB is used to calculate the weight of indicators.

Table 6. Weight of Indicators.

\begin{tabular}{|c|c|}
\hline Index layer & Weight \\
\hline B1 & 0.0954 \\
\hline B2 & 0.1601 \\
\hline B3 & 0.4673 \\
\hline B4 & 0.2772 \\
\hline
\end{tabular}

We use the AHP to calculate the index weight. Construct judgment matrix $S=\left(u_{i j}\right)_{p \times p}$

Table 7. Discriminant Matrix.

\begin{tabular}{|c|c|c|}
\hline & $\mathrm{C} 1$ & $\mathrm{C} 2$ \\
\hline $\mathrm{C} 1$ & 1 & $1 / 2$ \\
\hline $\mathrm{C} 2$ & 2 & 1 \\
\hline
\end{tabular}

MATLAB was used to calculate the maximum characteristic root of the judgment matrix $\lambda_{\max }=2$ MATLAB is used to calculate the weight of indicators.

Table 8. Weight of Indicators.

\begin{tabular}{|c|c|}
\hline Index layer & Weight \\
\hline $\mathrm{C} 1$ & 0.3333 \\
\hline $\mathrm{C} 2$ & 0.6667 \\
\hline
\end{tabular}

Construct judgment matrix $S=\left(u_{i j}\right)_{p \times p}$

Table 9. Discriminant Matrix.

\begin{tabular}{|c|c|c|c|}
\hline & C3 & C4 & C5 \\
\hline C3 & 1 & $1 / 2$ & 2 \\
\hline C4 & 2 & 1 & 3 \\
\hline C5 & $1 / 2$ & $1 / 3$ & 1 \\
\hline
\end{tabular}

MATLAB was used to calculate the maximum characteristic root of the judgment matrix $\lambda_{\max }=3.0092$ The consistency index should be calculated as follows:

$$
C I=\frac{\lambda_{\max }-n}{n-1}=\frac{3.0092-3}{3-1}=0.0046
$$

Mean random consistency index $R I=0.58$. Random consistency ratio:

$$
C R=\frac{C I}{R I}=\frac{0.0046}{0.58}=0.0079<0.10
$$

Therefore, the results of AHP have satisfactory consistency, that is, the distribution of weight coefficient is reasonable. MATLAB is used to calculate the weight of indicators.

Table 10. Weight of Indicators.

\begin{tabular}{|c|c|}
\hline Index layer & Weight \\
\hline C3 & 0.2970 \\
\hline C4 & 0.5396 \\
\hline C5 & 0.1634 \\
\hline
\end{tabular}

We use MATLAB to calculate the weight of indicators with the same method of calculation. In this study, the

\begin{tabular}{|c|c|c|c|c|c|}
\hline Index & & Weight & Index & & Weight \\
\hline \multirow{2}{*}{ B1 } & $\mathrm{C} 1$ & 0.031797 & & $\mathrm{C} 8$ & 0.020468 \\
\hline & $\mathrm{C} 2$ & 0.063603 & & C9 & 0.030748 \\
\hline \multirow{3}{*}{ B2 } & $\mathrm{C} 3$ & 0.047550 & & $\mathrm{C} 10$ & 0.151218 \\
\hline & $\mathrm{C} 4$ & 0.086390 & & $\mathrm{C} 11$ & 0.081497 \\
\hline & $\mathrm{C} 5$ & 0.026160 & \multirow{4}{*}{ B4 } & $\mathrm{C} 12$ & 0.133860 \\
\hline \multirow{3}{*}{ B3 } & \multirow{2}{*}{ C6 } & \multirow{2}{*}{0.048506} & & $\mathrm{C} 13$ & 0.075398 \\
\hline & & & & $\mathrm{C} 14$ & 0.043520 \\
\hline & C7 & 0.134816 & & $\mathrm{C} 15$ & 0.024447 \\
\hline
\end{tabular}
single weight value of the evaluation index determined by AHP above is as follows:

Table 11. Single Weight Value of Evaluation Index.

\subsection{Index data acquisition and weight assignment}

This research according to " Jianghua county government information disclosure annual report"; " Jianghua county economic and social development statistical bulletin"; "Annual report on environmental air quality of Jianghua yao autonomous county" ; "Assessment of ecological environment quality in Jianghua yao autonomous county from 2013 to 2017 ". And relevant research materials, the actual value of each index data acquisition, data fixed number of year of 2013 to 2017 . According to the relevant national standards "national forest city evaluation standard", "environmental impact evaluation standard" and the average level of similar cities, the standard reference value is determined. According to the evaluation standard of technical specification for evaluation of ecological environment condition (trial) (HJ/t192-2015), the evaluation of ecological environment quality of Jianghua Yao autonomous county was conducted by Hunan Environmental Monitoring Center Station. 
Table 12. Index Data and Index Evaluation.

\begin{tabular}{|c|c|c|c|c|c|c|}
\hline $\begin{array}{c}\text { Evaluation Index } \\
\text { Element Layer }\end{array}$ & $\begin{array}{c}\text { Index } \\
\text { Factor }\end{array}$ & 2013 & 2014 & 2015 & 2016 & 2017 \\
\hline \multirow{3}{*}{ B1 } & C1 & 62 & 60 & 69.3 & 69.5 & - \\
& C2 & Good & Good & Good & $\begin{array}{c}\text { Excellent } \\
\text { Excellent }\end{array}$ & - \\
\hline \multirow{2}{*}{ B2 } & C4 & $87 \%$ & - & $60 \%$ & $87 \%$ & - \\
& C5 & $100 \%$ & $100 \%$ & $100 \%$ & $100 \%$ & $100 \%$ \\
\hline \multirow{3}{*}{ B3 } & C7 & $95.83 \%$ & - & $98 \%$ & $95.13 \%$ & $90.90 \%$ \\
& C8 & 52.3 & 52 & 53.8 & 54 & - \\
& C9 & $78.93 \%$ & $88.88 \%$ & $86 \%$ & $90 \%$ & $100 \%$ \\
& C10 & $79.31 \%$ & $82.61 \%$ & - & - & $83.8 \%$ \\
& C11 & $100 \%$ & $100 \%$ & $100 \%$ & $100 \%$ & $100 \%$ \\
B4 & C12 & $76.85 \%$ & $76.80 \%$ & $77.66 \%$ & $78.50 \%$ & $78.80 \%$ \\
& C13 & 84.92 & - & 80.90 & - & - \\
& C14 & 44.04 & - & 40.05 & - & - \\
\hline
\end{tabular}

\section{Analysis on the rationality of urban}

\subsection{Single evaluation index analysis}

The data of 2014-2017 after the implementation of the plan is compared with the data of 2013 before the implementation of the plan. Evaluation impact factors were used to calculate the evaluation index method. The positive data was higher than that listed as 1 before the planning and lower than the ratio of the calculated annual data before the planning 2013. Negative data is lower than that listed in column 1 of 2013, and higher than that of 2013. The evaluation indexes are listed below.

Table 13. Evaluation Index.

\begin{tabular}{|c|c|c|c|c|}
\hline $\begin{array}{c}\text { Index } \\
\text { Factor }\end{array}$ & 2014 & 2015 & 2016 & 2017 \\
\hline C1 & 1 & 0.89 & 0.89 & - \\
\hline C2 & - & - & 1 & 1 \\
\hline C3 & - & 1 & 1 & - \\
\hline C4 & 1 & 1 & 1 & - \\
\hline C5 & 1 & 1 & 1 & 1 \\
\hline C6 & - & 1 & 0.99 & 0.94 \\
\hline C7 & 1 & 0.97 & 0.96 & - \\
\hline C8 & 1 & 1 & 1 & 1 \\
\hline C9 & 1 & - & - & 1 \\
\hline C10 & 1 & 1 & 1 & 1 \\
\hline C11 & 1 & 1 & 1 & 1 \\
\hline C12 & 0.99 & 1 & 1 & 1 \\
\hline C13 & - & 0.95 & - & - \\
\hline C14 & - & 0.9 & - & - \\
\hline C15 & - & 1 & - & - \\
\hline
\end{tabular}

\subsection{AHP score results}

With reference to the classification methods commonly used in the comprehensive index in relevant studies, the classification standards in this study were set as four levels, as shown in the following table ${ }^{[15]}$.

Table 14. Comprehensive Evaluation Index Classification.

\begin{tabular}{|c|c|c|c|c|}
\hline C & $>90$ & $89-80$ & $79-70$ & $<70$ \\
\hline $\begin{array}{c}\text { The } \\
\text { Evaluation } \\
\text { Results }\end{array}$ & Mostly & Partly & Rarely & Unreasonable \\
\hline
\end{tabular}

Table 15. The score table

\begin{tabular}{|c|c|c|c|c|c|}
\hline & Weight & Score & & Weight & Score \\
\hline C1 & 0.031797 & 92 & C8 & 0.020468 & 100 \\
\hline C2 & 0.063603 & 100 & C9 & 0.030748 & 100 \\
\hline C3 & 0.047550 & 100 & C10 & 0.151218 & 100 \\
\hline C4 & 0.086390 & 100 & C11 & 0.081497 & 100 \\
\hline C5 & 0.026160 & 100 & C12 & 0.133860 & 99 \\
\hline C6 & 0.048506 & 97 & C13 & 0.075398 & 95 \\
\cline { 4 - 6 } & C14 & 0.043520 & 90 \\
\hline C7 & 0.134816 & 97 & C15 & 0.024447 & 100 \\
\hline
\end{tabular}

By analytic hierarchy process, the environmental impact of urban master plan can be evaluated. The evaluation model composed of the final weight of this standard is very useful for assessing the environmental impact of urban planning plans.

After calculation, the B1 score of Jianghua Yao autonomous county is 9.28 . The score of B2 was 16; B3 scored 46.2. The score of B4 is 26.9. Therefore, the rationality of urban spatial distribution and development direction in Jianghua County can be scored 98.38.

\subsection{Conclusion of rationality analysis}


According to the index system factors in this paper, the main traffic lines in Jianghua are Luo Zhanjiang railway, Eight Horizontal" road network planning and construction of the main and secondary roads just to solve the problem. Among them, the external contact is convenient, the communication between the internal functional areas is convenient, and the accessibility is high. Moreover, the traffic noise generated by vehicle transportation on the main traffic trunk roads that have been built is also up to the standard and has little impact on the surrounding environment. The green belt coverage rate of main traffic lines is relatively high.

Living areas is divided into five groups, planning area of $6.98 \mathrm{~km}^{2}$, accounting for more than $27.86 \%$, hazardfree treatment rate of living garbage and centralized drinking water quality success rate is high, the water quality standard of $100 \%$, planning and implementation of living garbage classification first, recycle and reuse, and cannot be recovered by the sanitation department to non-hazardous waste plant concentrate processing, including sewage after treatment also recycle, housing construction area of $57.9 \mathrm{~m}^{2}$ per capita is at a higher level. Moreover, the per capita public green space area also reaches $10 \mathrm{~m}^{2}$ per person, reaching the level of national garden city, and the total scoring rate reaches $100 \%$,

\section{References}

1. Fu haiying, Hao jinmin, Analysis of urban spatial development direction based on smart growth -- a case study of Tai'an City in shandong province, In: Resources Science, 01:63-69. (2007)

2. Falasca, S.L., Ulberich, A.C., Ulberich, E., Developing an agro-climatic zoning model to determine potential production areas for castor bean (Ricinus communis L.), In: Ind. Crops Prod., Vol.40, pp. 185-191.(2012)

3. Zhai Jian, Jin Xiaochun, Spatial Analysis Method of GIS in Urban Planning, In: Urban Planning, S2,pp.130-135. (2014)

4. Amira Mersal, Environmental Planning for Sustainable Urban Development, In: Procedia Environmental Sciences, pp. 34. (2016)

5. Kultip Suwanteep, Takehiko Murayama, Shigeo Nishikizawa, Environmental Impact Assessment System in Thailand and Its Baroudy, A.A.E, Mapping and evaluating land suitability using a GIS-based model, In: CATENA, Vol.140, pp.96-104. (2016)

6. Baroudy, A.A.E, Mapping and evaluating land suitability using a GIS-based model, In: CATENA, Vol.140, pp.96104. (2016)

7. Min-ShunWang, Hsueh-TaoChien, Environmental behaviour analysis of high-rise building areas in Taiwan, In: BUILDING AND ENVIRONMENT, Vol.34, Issue 1, pp.8593. (1998)

8. Wang huizhi, Preliminary study on urban planning environmental impact assessment index system integrated with the concept of ecological civilization, In: City, 03, pp.38-41. (2014)

9. Chan, E. H. W., Lee, G. K. L., Critical factors for improving social sustainability of urban renewal projects, In: Social Indicators Research, Vol. 85, 02: 243-256. (2007)
G207 national road and S322 provincial road, which score low in terms of traffic convenience. The "Six Vertical and which is in line with the strategic positioning of green ecological development. The negative impact on ecological environment and social and humanistic environment of Jianghua Yao autonomous county is small.

Through research and analysis of this article, from the aspects of overall planning environmental impact assessment on the urban spatial distribution and spatial development direction of the Yao nationality autonomous county has carried on the macroscopic analysis, with qualitative and quantitative methods, the index data is analysed, and in the environmental aspects of the analysis conclusion: on the Yao autonomous county in 2014-2020, planning the urban spatial distribution and reasonable development direction, is suitable for the development of the city.

\section{Acknowledgement}

Hunan natural science foundation general project (project approval no. : 2018JJ2525)

National natural science foundation of China (project approval no. : 51308548)

10. 10.H. Y. Shang, F. Su, Evaluation and Forecasting: Urban Sustainable Development of Wuwei City in Gansu Province, In: Advanced Materials Research, Vols. 113-116, pp. 343-346. (2010)

11. Lin Liu, Yaoyu Lin, Ye Xiao, Puning Xue, Luyang Shi, Xin Chen, Jing Liu, Quantitative effects of urban spatial characteristics on outdoor thermal comfort based on the LCZ scheme,In: BUILDING AND ENVIRONMENT, Vol.143,pp.443-460. (2018)

12. Kazemi, H., Sadeghi, S., Akinci H, Developing a land evaluation model for faba bean cultivation using geographic information system and multi-criteria analysis (A case study: Gonbad-Kavous region, Iran), In: Ecol. Ind., Vol. 63, pp.37-47. (2016)

13. Yaser Ostovari, Afshin Honarbakhsh, Hamed Sangoony, Farhad Zolfaghari , Kimia Malekie, Ben Ingram, GIS and multi-criteria decision-making analysis assessment of land suitability for rapeseed farming in calcareous soils of semiarid regions, In: Ecological Indicators, vol.103, pp.479487. (2019)

14. Guzman-Sanchez, Salvador, Jato-Espino Daniel, Lombillo Ignacio, Assessment of the contributions of different flat roof types to achieving sustainable development, In: BUILDING AND ENVIRONMENT, Vol.141, pp.182-192. (2018)

15. Sarah Fretzer, Using the Ecopath approach for environmental impact assessment-A case study analysis, In: Ecological Modelling, pp.331.(2016) 